\title{
Preliminary investigation on presence of peste des petits ruminants in Dakawa, Mvomero district, Morogoro region, Tanzania
}

\begin{tabular}{|c|c|}
\hline $\begin{array}{l}\text { Authors: } \\
\text { Tebogo Kgotle } \\
\text { Christopher J. } \\
\text { Lughano J.M. } \\
\text { Gerald Misinz }\end{array}$ & $\begin{array}{l}\text { le }^{1} \\
\text { Kasanga }^{1} \\
\text { Kusiluka } \\
\end{array}$ \\
\hline $\begin{array}{l}\text { Affiliations: } \\
{ }^{1} \text { Department } \\
\text { Microbiology } \\
\text { Parasitology, S } \\
\text { University of } A \\
\text { Tanzania }\end{array}$ & $\begin{array}{l}\text { f Veterinary } \\
\text { and } \\
\text { okoine } \\
\text { griculture, }\end{array}$ \\
\hline $\begin{array}{l}{ }^{2} \text { Department } \\
\text { Medicine and } \\
\text { Sokoine Unive } \\
\text { Agriculture, Ta }\end{array}$ & $\begin{array}{l}\text { f Veterinary } \\
\text { Public Health, } \\
\text { rsity of } \\
\text { nzania }\end{array}$ \\
\hline $\begin{array}{l}\text { Corresponden } \\
\text { Tebogo Kgotle }\end{array}$ & $\begin{array}{l}\text { ce to: } \\
\text { le }\end{array}$ \\
\hline $\begin{array}{l}\text { Email: } \\
\text { tkgotlele@gm }\end{array}$ & ail.com \\
\hline $\begin{array}{l}\text { Postal addres } \\
\text { PO Box 3019, } \\
\text { Morogoro, Tar }\end{array}$ & $\begin{array}{l}\text { Chuo Kikuu, } \\
\text { Izania }\end{array}$ \\
\hline $\begin{array}{l}\text { How to cite th } \\
\text { Kgotlele, T., Ka } \\
\text { Kusiluka, L.J.M } \\
\text { G., 2014, 'Prel } \\
\text { investigation o } \\
\text { peste des peti } \\
\text { Dakawa, Mvor } \\
\text { Morogoro reg } \\
\text { Onderstepoor } \\
\text { Veterinary Res } \\
\text { Art. \#732, } 3 \text { pa } \\
\text { dx.doi.org/10. } \\
\text { v81i2.732 }\end{array}$ & $\begin{array}{l}\text { is article: } \\
\text { sanga, C.J., } \\
\text { I. \& Misinzo, } \\
\text { iminary } \\
\text { n presence of } \\
\text { ts ruminants in } \\
\text { nero district, } \\
\text { on, Tanzania', } \\
\text { Journal of } \\
\text { earch } 81(2) \text {, } \\
\text { ages. http:// } \\
\text { 4102/ojvr. }\end{array}$ \\
\hline $\begin{array}{l}\text { Note: } \\
\text { Proceedings o } \\
\text { One Health Co } \\
\text { Africa. Jointly } \\
\text { by the Southe } \\
\text { Centre for Infe } \\
\text { Surveillance a } \\
\text { National Instit } \\
\text { Research, helc } \\
\text { Crest Hotel in } \\
\text { Tanzania from } \\
\text { April 2013: htt } \\
\text { sacids.org/km } \\
\text { index.php?m= }\end{array}$ & $\begin{array}{l}\text { f the } 2 \text { nd } \\
\text { nference in } \\
\text { organised } \\
\text { n African } \\
\text { ctious Disease } \\
\text { d the Tanzania } \\
\text { ute for Medical } \\
\text { at the Snow } \\
\text { Arusha, } \\
\text { 16th to 19th } \\
\text { p://www. } \\
\text { s/frontend/ } \\
119 \text {. }\end{array}$ \\
\hline 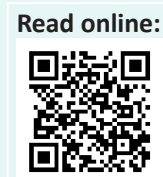 & $\begin{array}{l}\text { Scan this QR } \\
\text { code with your } \\
\text { smart phone or } \\
\text { mobile device } \\
\text { to read online. }\end{array}$ \\
\hline
\end{tabular}

Peste des petits ruminants (PPR) is an acute viral disease of small ruminants characterised by the sudden onset of depression, fever, oculonasal discharges, sores in the mouth, foulsmelling diarrhoea and death. For many years, in Africa, the disease was mainly confined to West and Central Africa but it has now spread southwards to previously PPR-free countries including Tanzania, Democratic Republic of Congo and Angola. The disease was first reported in Tanzania in 2008 when it was confined to the Northern Zone districts bordering Kenya. Presence of the disease has also been confirmed in southern Tanzania especially Mtwara region. Recently, a suspected outbreak of PPR in Dakawa area, Mvomero district, Morogoro region was reported. Clinical samples (lungs, intestines, lymph nodes, whole blood and sera) from suspected goats $(n=8)$ and sheep $(n=1)$ were submitted to Sokoine University of Agriculture for analysis. Molecular diagnosis by amplification of the nucleoprotein gene and the fusion gene of PPR virus (PPRV) using PPRV specific primers was done. Five goats and the sheep were positive for PPRV after performing RT-PCR. To our knowledge, this is the first report confirming the presence of PPR in the Mvomero district of the Morogoro region, Tanzania. Hence, more efforts should be put in place to prevent the spread of PPR in Tanzania.

\section{Introduction}

Peste des petits ruminants (PPR) is a highly infectious disease of small domestic ruminants and small wild ruminants, such as antelopes, impala and gazelles (Muse et al. 2012a). The disease is currently considered one of the main transboundary animal diseases that constitute a threat to small ruminant production in many developing countries (Banyard et al. 2010). The disease is caused by the peste des petits virus (PPRV), a member of the genus Morbillivirus of the Paramyxoviridae family (Kwiatek et al. 2010). The PPR virus can be transmitted when animals sneeze or cough, therefore the virus is found in discharge from the eyes, nose and mouth of infected animals and affected animals that do not show signs of the disease (Roeder et al. 1999). Contact and movement of animals from affected to unaffected areas play an important role in transmitting the disease, especially where a communal grazing system is practiced. As a result, PPR is on the list of economically important animal diseases whose occurrence has to be reported to the World Organisation for Animal Health (OIE) (FAO-EMPRES 2009).

Peste des petits ruminants was first described in West Africa in the 1940s (Khan et al. 2008). But with the advent of specific diagnostic tests, the geographical distribution of the disease was found to have expanded in the late 1980s and mid-1990s (FAO-EMPRES 2009). Currently, PPR is present in Central, East and West Africa, Asia, and the Near and Middle East (Geerts 2009). It is believed that the development of trade relations, transport, tourism and migration of wild animals susceptible to PPR have contributed to the spread of the disease beyond the boundaries of West Africa (Kaukarbayevich 2009). In Tanzania, PPR was first reported in 2008 in the Northern Zone districts bordering Kenya (Karimuribo et al. 2011). The disease was later introduced into southern Tanzania in 2009 through newly purchased goats from a livestock market located about $700 \mathrm{~km}$ away on the outskirts of Dar es Salaam City (Muse et al. 2012a). There is no official confirmation of one of the possible routes of PPR transmission from the northern parts to the southern parts of Tanzania.

The objective of this study was to confirm whether suspected cases seen in goats and sheep in Mvomero district, Morogoro region were caused by PPRV and establish one of the possible routes of transmission of PPR from northern to southern Tanzania. Because of the geographical position of Morogoro, it is the centre of the regional roads network to the coast, Dar es Salaam, Dodoma and Iringa. 


\section{Material and methods Study area}

The study was carried out in Dakawa, Mvomero district in Morogoro region. Morogoro region is located on the eastern side of Tanzania Mainland. The area was purposively targeted following reports of suspected PPR outbreak.

\section{Samples}

Clinical samples (lungs, intestines, lymph nodes, whole blood and sera) from eight goats and one sheep were submitted to Sokoine University of Agriculture for analysis.

\section{Sample preparation and laboratory analysis}

Buffy coat was prepared from whole blood using Histopaque $^{\circledR}-1077$ (Sigma-Alderich, St. Louis), transferred into a sterile microfuge tube and stored at $-80{ }^{\circ} \mathrm{C}$ until RNA extraction. Tissues from the same animal were pooled together and homogenised in F-12 Nutrient Mixture (Ham) 1X (Invitrogen, New York) to make a 10\% tissue suspension. The tissue suspension was then centrifuged at room temperature and stored at $-80{ }^{\circ} \mathrm{C}$ until RNA extraction. Viral RNA was recovered from buffy coat, sera and homogenised tissue samples using QIAamp Viral RNA Mini extraction kit (Qiagen, Hilden, Germany) according to the manufacturer's instructions. Extracted RNA was amplified in a $25 \mu \mathrm{L}$ reaction using AgPath-ID One-Step RT-PCR kit (Applied Biosystems, Courtaboeuf, France) using PPRV-specific primers: NP3 (5'-TCTCGGAAATCGCCTCACAGACTG-3') and NP4 (5'-CCTCCTCCTGGTCCTCCAGAATCT-3') from Couacy-Hymann et al. (2002), PPRV-F-f (5'- GAGACTGAGTTTGTGACCTACAAGC-3') and PPRVF-r (5'-ATCACAGTGTTAAAGCCTGTAGAGG-3') from Forsyth and Barrett (1995). Amplification was carried out in GeneAmp PCR System 9700 (Applied Biosystems, Foster City, USA) followed by electrophoresis on $1.5 \%$ agarose gel. The DNA was visualised by ultraviolet fluorescence with positive samples showing $351 \mathrm{bp}$ bands for NP3/NP4 and 322 bp bands for PPRV-F-f/PPRV-F-r primers.

\section{Results and discussion}

Clinical signs observed were nasal discharges, diarrhoea and oral ulcers, as shown in Figure 1. These observations are consistent with previous reports from Muse et al. (2012a, 2012b) done on PPR in Tanzania.

Post mortem showed enlarged and congested lymph nodes associated with the gastrointestinal and/or respiratory tract, as shown in Figure 2. These findings have been reported by Roeder et al. (1999), Centre For Food Security And Public Health (CFSPH) (2008), OIE (2008) and Chauhan et al. (2009).

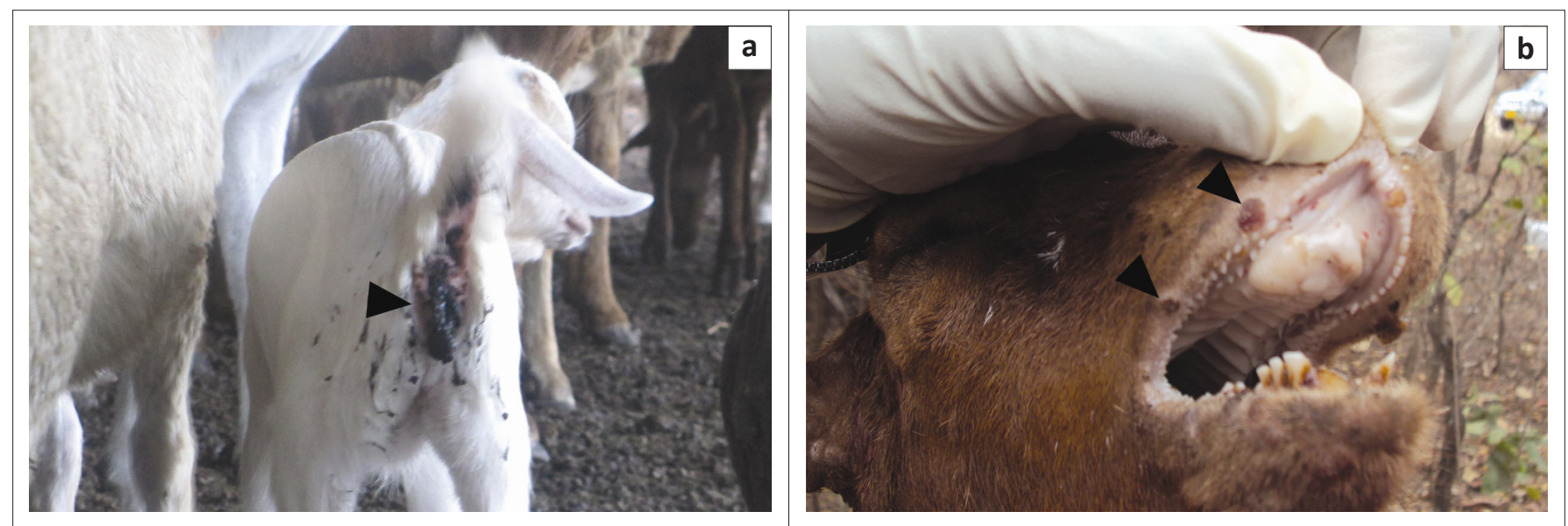

FIGURE 1: PPR-suspected animals showing (a) diarrhoea and (b) erosions on the palate and gums (see arrow heads).
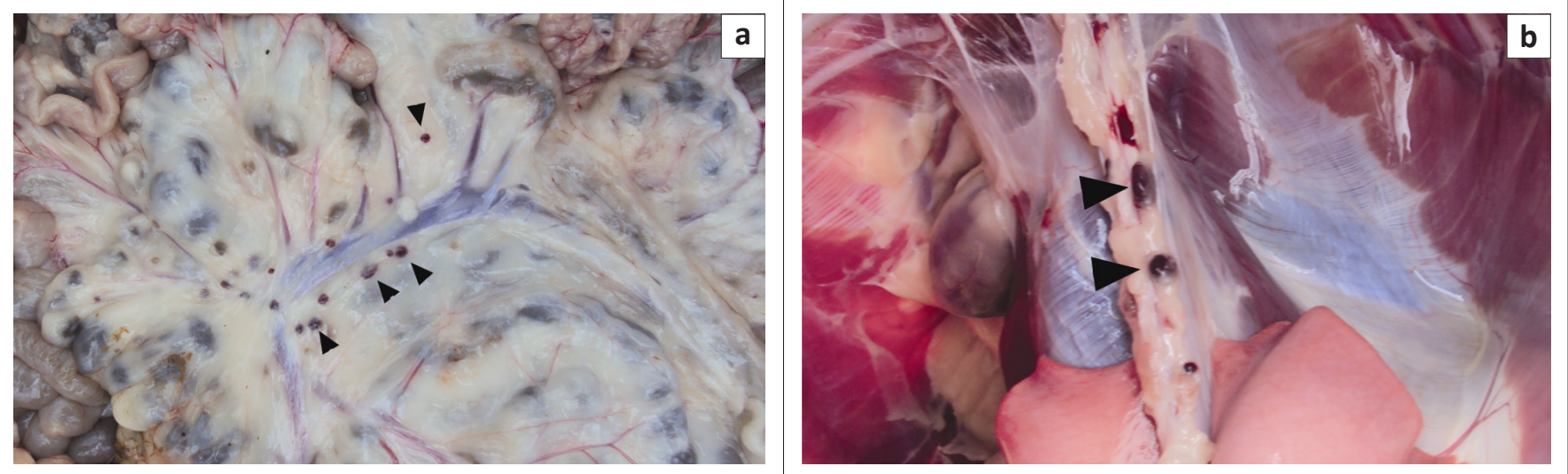

FIGURE 2: Congested lymph nodes in the (a) respiratory and (b) gastrointestinal systems of PPR-suspected animals (see arrow heads). 
Virus presence was confirmed in tissue samples using reverse transcription polymerase chain reaction using PPRV-specific primers targeting nucleoprotein and fusion protein genes. Six out of the nine animals were positive for fusion protein while only four animals were positive for nucleoprotein. Nucleoprotein gene transcripts are more abundant in infected tissues compared to transcripts of the fusion gene required for viral attachment and transmission on epithelial tissues, thus the ability of primers to detect the virus is affected by the stage of infection and time of sample collection (Luka et al. 2012).

\section{Conclusion}

This study confirms for the first time the presence of PPR in the Morogoro region in Tanzania. Since vaccination against PPR has never been carried out, this is a result of natural transmission of the virus under field conditions. Given the position of the Morogoro region, more studies need to be carried out in order to put in place effective control and prevention measures to contain the possible spread of the disease to other regions of Tanzania.

\section{Acknowledgements}

The authors would like to thank Mr Kochuchu and farmers in Dakawa for their cooperation, contributions and time. This study was supported by a grant from the Wellcome Trust to the Southern African Centre for Infectious Disease Surveillance (SACIDS), Sokoine University of Agriculture, Morogoro, Tanzania.

\section{Competing interests}

The authors declare that they have no financial or personal relationship(s) that may have inappropriately influenced them in writing this article.

\section{Authors' contributions}

T.K. (Sokoine University of Agriculture) was responsible for project design, prepared the samples and performed most of the experiments. C.J.K. (Sokoine University of Agriculture), L.J.M.K. (Sokoine University of Agriculture) and G.M.
(Sokoine University of Agriculture) provided mentoring and technical assistance, and carried out project design and interpretation of results.

\section{References}

Banyard, A.C., Parida, S., Batten, C., Oura, C., Kwiatek, O. \& Libeau, G., 2010, 'Global distribution of peste des petits ruminants and prospects for improved diagnosis and control', Journal of General Virology 91(12), 2885-2897. http://dx.doi. org/10.1099/vir.0.025841-0

Centre for Food Security and Public Health (CFSPH), 2008, Peste des petits ruminants, viewed 04 March 2012, from http://www.cfsph.iastate.edu/Factsheets/pdfs/ peste_des_petits_ruminants.pdf.

Chauhan, H.C., Chandel, B.S., Kher, H.N., Dadawala, A.I. \& Agrawal, S.M., 2009, 'Peste des petits ruminants virus infection in animals', Veterinary World 2(4), 150-155.

Couacy-Hymann, E., Roger, F., Hurard, C., Guillou, J.P., Libeau, G. \& Diallo, A., 2002, 'Rapid and sensitive detection of peste des petits ruminants virus by a polymerase chain reaction assay', Journal of Virological Methods 100, 17-25. http://dx.doi. org/10.1016/S0166-0934(01)00386-X

FAO-EMPRES, 2009, Transboundary Animal Diseases Bulletin 33, Food and Agriculture Organization Emergency Prevention System (FAO-EMPRES), Rome.

Forsyth, M.A. \& Barrett, T., 1995, 'Evaluation of polymerase chain reaction for the detection and characterisation of rinderpest and peste des petits ruminants viruses for epidemiological studies', Virus Research 39, 151-163. http://dx.doi. org/10.1016/0168-1702(95)00076-3

Geerts, S., 2009, 'Goat plague or peste des petits ruminants (PPR)', EAZWV Transmissible Disease Fact Sheet 25, Institute of Tropical Medicine, Antwerp.

Karimuribo, E.D., Loomu, P.M., Mellau, L.S.B. \& Swai, E.S., 2011, 'Retrospective study on sero-epidemiology of peste des petits ruminants before its official confirmation in northern Tanzania in 2008', Research Opinions in Animal \& Veterinary Sciences 1(3), 184-187.

Kaukarbayevich, K.Z., 2009, 'Epizootological analysis of PPR spread on African continent and in Asian countries', African Journal of Agricultural Research 4(9), 787-790.

Khan, M.A., Hussain, S.N., Bahadar, S., Ali, A. \& Shah, I.A., 2008, 'An outbreak of peste des petits ruminants (PPR) in goats in district Chitral, N.W.F.P., Pakistan', Journal of Agricultural and Biological Science 3(2), 19-22.

Kwiatek, O. et al., 2010, 'Quantitative one-step real-time RT-PCR for the fast detection of the four genotypes of PPRV', Journal of Virological Methods 165, 168-177. $\mathrm{http}: / / \mathrm{dx}$.doi.org/10.1016/j.jviromet.2010.01.014

Luka, P.D., Ayebazibwe, C., Shamaki, D., Mwiine, F.N. \& Erume, J., 2012, 'Sample type is vital for diagnosing infection with peste des petits ruminants virus by reverse transcription PCR', Journal of Veterinary Science 13(3), 323-325. http://dx.doi. org/10.4142/jvs.2012.13.3.323

Muse, E.A. et al., 2012a, 'Epidemiological investigation into the introduction and factors for spread of Peste des Petits Ruminants, southern Tanzania', Onderstepoort Journal of Veterinary Research 79(2), 49-54. http://dx.doi. org/10.4102/ojvr.v79i2.457

Muse, E.A., Matondo, R.B., Karimuribo, E.D., Misinzo, G., Albano, M.O. \& Gitao, G.C., $2012 \mathrm{~b}$, 'Clinico-pathological findings of the 2011 outbreak of peste des petits ruminants (PPR) in Tandahimba district, southern Tanzania', Research Opinions in Animal and Veterinary Sciences 2(4), 256-262.

OIE, 2008, Manual of diagnostic tests and vaccines for terrestrial animals, viewed 22 May 2012, from http://www.oie.int/fileadmin/Home/eng/Health_standards/ tahm/2.07.11_PPR.pdf, pp. 1036-1046, World Organization for Animal Health, Paris.

Roeder, P.L., Obi, T.U., Taylor, W. \& Diallo, A., 1999, Recognizing peste des petits ruminants: A field manual, Food and Agriculture Organization Emergency Prevention System (FAO-EMPRES) (Livestock) Animal Health Service, Rome. 